\title{
ON THE PATHOGENESIS OF RENAL FAILURE ASSOCIATED WITH MULTIPLE MYELOMA. ELECTROPHORETIC AND CHEMICAL ANALYSIS OF PROTEIN IN URINE AND BLOOD SERUM ${ }^{1}$
}

\author{
BY SAM S. BLACKMAN, JR., W. HALSEY BARKER, MARY V. BUELL, AND \\ BERNARD D. DAVIS
}

(From the Departments of Pathology and Medicine, The Johns Hopkins University, Baltimore)

(Received for publication June 10, 1943)

One of the factors concerned in the pathogenesis of renal insufficiency in many cases of Bright's disease is mechanical obstruction of glomeruli and tubules by accumulations of fibrin and other more abundant protein coagula. It has been shown by means of chemical and electrophoretic analysis of protein excreted in the urine of such cases that there is a close correlation between the concentration of globulin and total protein, and the rate at which protein coagula collect within the kidney (1 to 3 ). The evidence suggests, further, that the hyaline coagula, not identifiable as fibrin, consist chiefly of precipitated globulins.

The example of multiple myeloma, BenceJones proteinuria, and renal insufficiency described here represents a type of Bright's disease in which renal insufficiency depends chiefly on obstruction of tubules by precipitation of BenceJones protein. The blood serum of this case contained a fraction comprising 24.6 per cent of the total serum protein, and it moved electrophoretically like a beta globulin. The protein in the urine salted-out like a globulin, moved electrophoretically like a beta globulin, and exhibited the solubility characteristics typical of a Bence-Jones protein.

\section{CASE REPORT}

M. T., History No. 232997, a white man, 45 years old, was first examined on June 30,1941, and died on January 25, 1942.

History. Six months before examination, the patient noticed weakness and fatigue. He broke a rib by merely leaning against a dull instrument with which he was working. During the next few months, there appeared dyspnea, dizziness, occasional numbness and tingling in the legs, nocturia on occasions, blurring of vision, and vomiting.

Physical examination. He was somewhat obese, and

1 Aided by a grant from the Rockefeller Foundation Fluid Research Fund of the School of Medicine of the Johns Hopkins University. was very pale. The blood pressure varied from 130/80 to $170 / 80$ ( 3 determinations in 6 months). The temperature was elevated nearly every day $\left(99^{\circ}\right.$ to $100^{\circ}$ usually). The tip of the spleen was palpable. Blood: The red blood cell count was $1,200,000$; the hemoglobin was 30 per cent (4.2 grams); the white blood cell count was 4,200; differential was normal, except for 9 per cent myelocytes. Serum protein was 6.4 to 7.0 grams per cent ( 5 determinations in 5 months). Fractionation of the serum by Howe's sulfate method showed in July, albumin 4.76 grams, globulin 1.66 grams (A/G 74/26); and in January, albumin 4.94 grams, globulin 1.93 grams (A/G 72/28). One electrophoretic analysis of serum was made (Figure 1), and showed albumin (albumin plus alpha 1), 53.9 per cent; alpha globulin, 12.9 per cent; beta globulin, 24.6 per cent; gamma globulin, 8.6 per cent. Serum cholesterol was $167 \mathrm{mgm}$. per cent. Roentgenograms: There were numerous small lesions in skull, mandible, ribs, scapulae, and pelvic bones, suggesting multiple myeloma. Sternal puncture: Most of the cells obtained were characteristic myeloma cells ("plasma" cell type). The urine was very pale and clear. It contained large quantities of a Bence-Jones protein which, on being heated, precipitated at low temperature, disappeared on boiling, reappeared on cooling, and dissolved in strong acetic acid. Many examinations of the urine were made, and usually it became clear on boiling. Occasionally, however, slight cloudiness persisted at the boiling point. It was always evident that nearly all of the protein was soluble at high temperature. No red blood cells, occasional leukocytes, and rare casts were found microscopically.

Course of the disease. Repeated transfusions were given, but the anemia increased, nose-bleeds developed, and there was evidence of progressive renal insufficiency.

When the patient was first examined, the blood NPN was $106 \mathrm{mgm}$. per cent. During the next 5 months it rose gradually to $156 \mathrm{mgm}$. per cent, and the urea clearance was found to be 3 and 4 per cent of normal standard. Death occurred 2 months later, about 1 year after the onset of symptoms. Permission to perform an autopsy could not be obtained.

Materials examined and methods used. During the last

2 The protein described by Longsworth (4) as alpha 1 globulin has been found by Davis (3) to be even more soluble on fractional salting-out than electrophoretic serum "albumin," and we have therefore included it with the "albumin" fraction of the blood serum. 
5 months of the disease, 12 twenty-four hour specimens of urine, varying in volume from 1,200 to $2,050 \mathrm{cc}$., were collected, and samples of each were analyzed by a chemical method for total protein and for the relative proportion of albumin and globulin. The total protein was precipitated by means of 20 per cent trichloroacetic acid. Globulins were precipitated by Howe's primary and secondary potassium phosphate mixture (5). Nitrogen determinations were done by the macro-Kjeldahl method. The methods used for collection and preservation of urine, and the technique employed in the chemical analyses of urinary protein, have been described in detail (1).

Electrophoretic analysis of blood serum and urine was performed by the modification of the apparatus of Tiselius described by Longsworth and MacInnes (6). The urinary proteins were precipitated by saturation with ammonium sulfate, filtered, redissolved, and dialyzed in running tap water until essentially free of ammonia. They were then dialyzed against a barbital buffer of ionic strength 0.1 and pH 8.5. The electrophoretic measurements were made of the ascending pattern. The mobilities of the various protein fractions were not determined.

Results. The results of the urinalyses are shown in Table I. The total protein in the 12 specimens of urine varied from 0.475 to 0.744 grams per cent. Nearly all of the protein in each specimen was found to be globulin by both the chemical and electrophoretic methods of analysis. The largest amount of albumin in any of the specimens was found 9 days before death when the urine contained 20 per cent albumin and 80 per cent globulin. The single specimen of blood serum which was analysed electrophoretically contained 24.6 per cent of beta globulin, the normal usually being about 15 per cent or less of the total protein $(7,8)$.

\section{DISCUSSION}

There is evidence that Bence-Jones proteins originate from cells of the bone-marrow (9); and it has been found that there are a number of Bence-Jones proteins which may differ from each other in solubility (10), antigenic properties $(11,12)$, electrophoretic mobility $(7,13$ to 15$)$, and molecular size (15 to 17 ).

It seems evident, and it has been shown to be true, that in cases of multiple myeoloma with Bence-Jones proteinuria, the protein may be demonstrated in the blood serum $(14,15,18$ to 20). Many of the Bence-Jones proteins have been found to salt-out $(14,15,19,21,22)$ and to behave electrophoretically like globulins $(14,15)$. In the case described above, the blood serum contained an excess (24.6 per cent) of electrophoretic beta globulin. Most of the urinary protein moved electrophoretically like beta globulin, salted-out like a globulin, and exhibited the solubility characteristics, when heated, boiled, and cooled, typical of a Bence-Jones protein. It seems clear that electrophoretic beta globulin of the serum was excreted in the urine as Bence-Jones protein.

The blood serum of this case, fractionated on two occasions by the Howe sulfate method, appeared to contain an increased proportion of albumin (72 and 74 per cent of the total protein). Electrophoretic fractionation, however, showed only $\mathbf{5 3 . 9}$ per cent albumin. Similar differences in the results of chemical and electrophoretic analyses have been described by others $(14,15)$. One case of apparent hyperalbuminemia reported was found to be due to the presence in

TABLE I

Chemical and electrophoretic fractionation of urinary protein

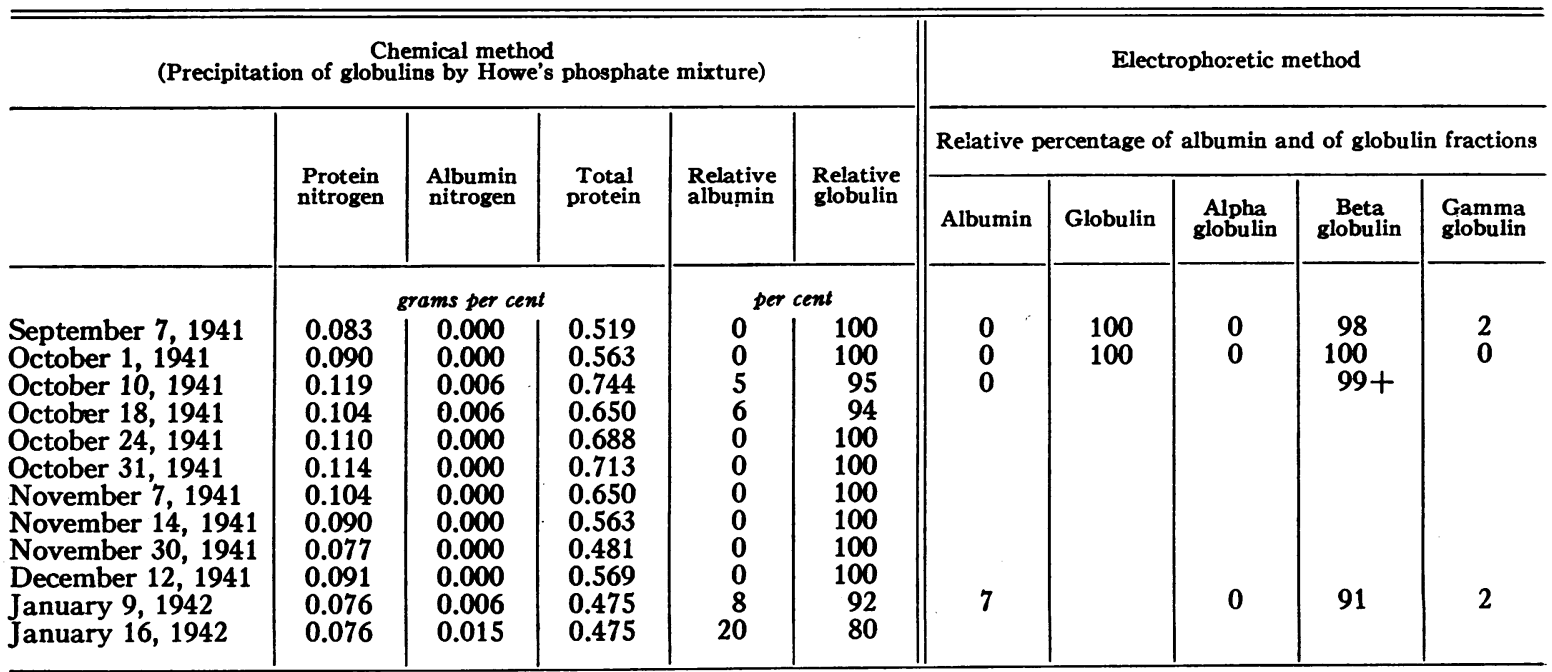


the serum of a protein which had the electrophoretic mobility of beta globulin, and was excreted in the urine as Bence-Jones protein. In the urine, it maintained the electrophoretic mobility of beta globulin and salted-out like a globulin.

It is not clear why Bence-Jones protein is excreted in the urine of some cases of myeloma with Bence-Jones proteinemia and not in others. The molecular weights of the Bence-Jones proteins so far determined have been found to be in the neighborhood of $37,000(15,16,23,24)$. Proteins of this molecular size might be expected to pass through normal glomerular capillaries, since the Bence-Jones proteins are smaller than serum albumin whose molecular weight is approximately 65,000 (25). There is evidence, however, suggesting that in addition to molecular size, other as yet unrecognized factors are also concerned in determining the presence of BenceJones proteinuria. The excretion of serum albumin in many cases, in addition to BenceJones protein, seems to require some other explanation; and a case was recently reported in which there was hyperbeta-globulinemia without Bence-Jones protein in the urine, although the molecular size of the abnormal serum beta globulin was consistent with that of other BenceJones proteins which were excreted in the urine $(14,15)$.

In some cases of myeloma, a form of renal insufficiency develops, due chiefly to obstruction of tubules by precipitated Bence-Jones protein (26 to 30). The suggestion has been made that prolonged Bence-Jones proteinuria of large quantity may be necessary for the development of this type of renal insufficiency $(29,31)$. Such an explanation is supported by the association of marked chronic proteinuria and progressive renal insufficiency in the case described in this paper, and also by recent studies concerning the effect of proteinuria on the kidney (1 to 3 ). Chemical and electrophoretic analyses of urinary protein have indicated that, in various forms of acute and chronic Bright's disease, the rate at which protein coagula collect in glomeruli and tubules is probably determined chiefly by the presence of high relative proportions of globulin (30 to 35 per cent or more of the total protein) in urine which contains total protein in high con-

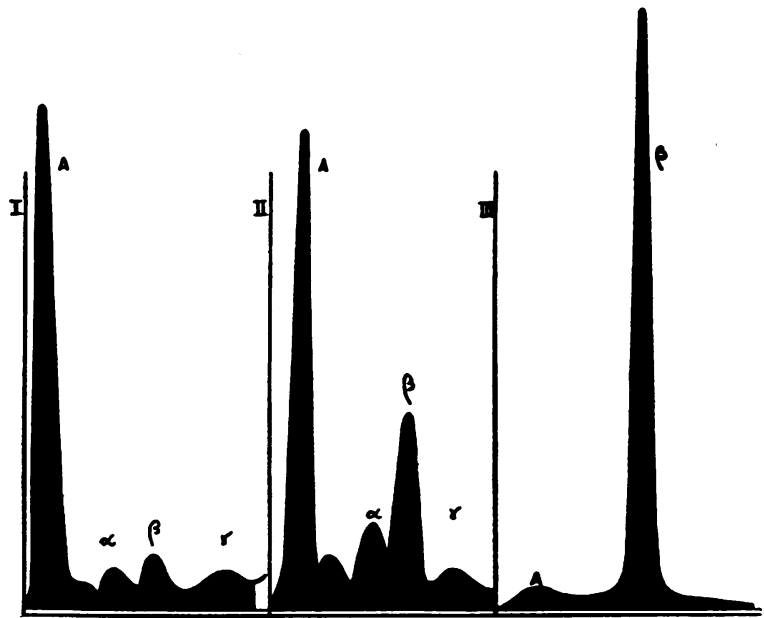

Fig. 1. Electrophoretic Patterns (Ascending Limbs) of Normal Human Blood Serum (I), aNd of the Serum (II) and Urine (III) of the Patient (M.T.) WITH Multiple MYeloma

centration ( 0.5 per cent or more). In cases of lipoid nephrosis, low proportions of globulin in the urine are associated with the absence of appreciable numbers of protein coagula in the kidney and the failure of renal insufficiency to develop (1 to 3,32 ).

The mechanism responsible for precipitation of Bence-Jones and other serum proteins within the kidney is probably concerned not only with the concentration of the proteins in the urine but also with other factors which remain to be investigated. It is probable, however, that the concentration of salts and urea in the urine are important. Under these conditions, the proteins salting-out as globulins would doubtless precipitate in the kidney, as in the test tube, more readily than the albumins. The analyses of urinary proteins excreted in Bright's disease of various types $(1$ to 3,32$)$, including the present case of renal failure with myeloma, indicate that it is chiefly the globulins, rather than albumins, which collect within the glomeruli and obstruct the renal tubules.

\section{SUMMARY}

The protein in the urine of a patient with multiple myeoloma and progressive renal insufficiency was shown by the usual solubility methods to be a Bence-Jones protein. The urine was also analyzed electrophoretically and by a chemical method. These two methods gave 
very nearly identical results. By both methods of analysis, the Bence-Jones protein behaved like a globulin. Electrophoretically it moved like the beta globulin of normal blood plasma.

The total plasma protein of the patient was normal, but there was a marked increase in the electrophoretic beta globulin fraction, which was excreted in the urine as Bence-Jones protein.

During the period of observation, the concentration of protein in the urine varied from $\mathbf{0 . 4 7 5}$ to 0.744 grams per cent, and the proportion of Bence-Jones protein usually varied from 92 to 100 per cent of the total. The evidence suggests that in multiple myeloma, as in other forms of Bright's disease, the development of that portion of renal insufficiency which is caused by the precipitation of plasma proteins within the kidney is determined chiefly by the duration of high concentrations in the urine of proteins which have the salting-out and electrophoretic properties of globulins.

\section{BIBLIOGRAPHY}

1. Blackman, S. S., Goodwin, W. E., and Buell, M. V., On the relation between the concentration of total protein and of globulin in the urine and the pathogenesis of certain renal lesions in Bright's disease. Bull. Johns Hopkins Hosp., 1941, 69, 397.

2. Blackman, S. S., and Davis, B. D., Electrophoretic and Kjeldahl analysis of protein in nephritic urine and the effect of proteinuria on the human kidney. South. M. J., 1943, 36, 247.

3. Blackman, S. S., and Davis, B. D., Electrophoretic and chemical analysis of protein in nephritic urine. J. Clin. Invest., 1943, 22, 545.

4. Longsworth, L. G., Recent advances in the study of proteins by electrophoresis. Chem. Rev., 1942, 30, 323.

5. Howe, P. E., The relative precipitating capacity of certain salts when applied to blood serum or plasma and the influence of the cation in the precipitation of proteins. J. Biol. Chem., 1923, 57, 241.

6. Longsworth, L. G., and MacInnes, D. A., Electrophoresis of proteins by the Tiselius method. Chem. Rev., 1939, 24, 271.

7. Longsworth, L. G., Shedlovsky, T., and MacInnes, D. A., Electrophoretic patterns of normal and pathological human blood serum and plasma. J. Exper. Med., 1939, 70, 399.

8. Luetscher, J. A., Electrophoretic analysis of plasma and urinary proteins. J. Clin. Invest., 1940, 19, 313.

9. Meyler, L., Bence-Jones' proteinuria. Arch. Int. Med., 1936, 57, 708.

10. Hewitt, L. F., Bence-Jones proteins. Biochem. J., 1929, 23, 1147.
11. Bayne-Jones, S., and Wilson, D. W., Immunological reactions of Bence-Jones proteins. Bull. Johns Hopkins Hosp., 1922, 33, 119.

12. Hektoen, L., and Welker, W. H., Immunological differences of crystalline Bence-Jones proteins. Biochem. J., 1940, 34, 487.

13. Kekwick, R. A., Serum proteins in multiple myelomatosis. Biochem. J., 1940, 34, 1248.

14. Gutman, A. B., et al., Fractionation of serum proteins in hyperproteinemia, with special reference to multiple myeloma. J. Clin. Invest., 1941, 20, 765.

15. Moore, D. H., Kabat, E. A., and Gutman, A. B., Bence-Jones proteinemia in multiple myeolma. J. Clin. Invest., 1943, 22, 67.

16. Svedberg, T., and Sjögren, B., The molecular weight of Bence-Jones protein. J. Am. Chem. Soc., 1929, $51,3594$.

17. McFarlane, A. S., Behavior of urinary proteins in ultracentrifuge. Biochem. J., 1935, 29, 1202.

18. Kydd, D. M., Bence-Jones protein in serum. J. Biol. Chem., 1934, 107, 747.

19. Cantarow, A., Bence-Jones proteinemia in multiple myeloma. Am. J. M. Sc., 1935, 189, 425.

20. Packalén, T., A case of myeloma with spontaneously crystallizing protein in blood serum and urine. Acta med. Scandinav., 1939, 100, 1.

21. Hopkins, F. G., and Savory, H., A study of BenceJones protein, and of the metabolism in three cases of Bence-Jones proteinuria. J. Physiol., 1911, 42, 189.

22. Shirer, J. W., Duncan, W., and Haden, R. L., Hyperproteinemia due to Bence-Jones protein in myelomatosis. Arch. Int. Med., 1932, 50, 829.

23. Bull, H. B., Protein structure. Advances in Enzymol., 1941, $1,1$.

24. Pedersen, K. O., Animal proteins. The Ultracentrifuge, Svedberg and Pedersen, Oxford, 1940, 382.

25. Pedersen, K. O., Serum proteins. The Ultracentrifuge, Svedberg and Pedersen, Oxford, 1940, 372.

26. Thannhauser, S. J., and Krauss, E., Über eine degenerative Erkrankung der Harnkanälchen bei Bence-Jones'scher Albuminurie mit Nierenschwund. Deutsches Arch. f. klin. Med., 1920, 133, 183.

27. Bohnenkamp, H., Zur Frage der Nephrosen. Virchow's Arch. f. path. Anat., 1922, 236, 380.

28. Forbus, W. D., Perlzweig, W. A., and Burwell, J. C., Effect of Bence-Jones excretion on kidneys. South M. J., 1933, 26, 361.

29. Forbus, W. D., Perlzweig, W. A., Parfentjev, I. A., and Burwell, J. C., Bence-Jones protein excretion and its effect upon kidney. Bull. Johns Hopkins Hosp., 1935, 57, 47.

30. Bell, E. T., Renal lesions associated with multiple myeloma. Am. J. Path., 1933, 9, 393.

31. Bodansky, M., and Bodansky, O., Biochemistry of Disease. MacMillan, New York, 1940. BenceJones proteinuria. p. 107.

32. Hiller, A., McIntosh, J. F., and Van Slyke, D. D., Excretion of albumin and globulin in nephritis. J. Clin. Invest., 1927, 4, 235. 